\title{
PENGEMBANGAN SOSIAL PADA BANK SAMPAH TRI ALAM LESTARI (TAL) MELALUI PELATIHAN KEWIRAUSAHAAN
}

\author{
Didip Diandra $^{1^{*}}$ \\ ${ }^{1}$ Ilmu Administasi Bisnis, Fakultas Manajemen dan Kepemimpinan, Tanri Abeng University \\ Jl. Swadarma Raya No 58, Ulujami, Pesanggrahan, Jakarta Selatan 12250 \\ Email Penulis Korespodensi: didip.diandra@tau.ac.id
}

\begin{abstract}
Abstrak
Kewirausahaan sosial menjadi wadah bagi pelaku usaha sosial untuk menggagas, memimpin dan melaksanakan strategi pemecahan masalah sosial secara inovatif melalui kerja sama dalam semua jenis jaringan sosial, serta menjalankan kegiatan usaha yang bernilai sosial di lingkungan masyarakat. Kewirausahaan sosial (masalah sosial, budaya, dan lingkungan) sering kali diasosiasikan dengan sukarelawan (voluntary) dan bukan untuk keuntungan semata (not-for profit). Sampah masih menjadi permasalahan di beberapa daerah. Sebagai ibukota, Jakarta masih menyimpan banyak masalah dengan sampah yang terselesaikan dengan baik sehingga menimbulkan masalah pada lingkungan. Namun bagi sebagian kecil masyarakat, sampah dipandang sebagai peluang yang bisa diproses untuk mendulang uang dari barang-barang yang dibuang. Ilmu kewirausahaan tidak hanya membahas masalah untung dan rugi saja. Apalagi jika dikaitkan dengan masalah sosial maka akan membawa misi sosial, menciptakan inovasi sosial, serta membuat perubahan sosial yang signifikan ditengah masyarakat. Kehadiran Ibu Tri Sugiarti melalui Bank Sampah TAL ditengah masyarakat dianggap sangat penting dan berkontribusi positif terhadap lingkungan sekitar, namun masih menyimpan masalah dalam manajemen kewirausahaannya yaitu permasalahan yang terkait dengan perencanaan pemasaran, prosedur operasional, standar dan quality control yang masih lemah. Oleh karena itu, perlu adanya pelatihan pengembangan kewirausahaan sosial pada Bank Sampah Tri Alam Lestari untuk menggali potensi kewirausahaan yang sudah ada, lalu mengembangkannya dengan ilmu kewirausahaan dasar dan sosial. Pelatihan ini diberikan dalam bentuk mini workshop berupa sosialisasi serta evaluasi penilaian pada unit usaha yang sedang berjalan. Hasil dari pelatihan didapatkan bahwa entrepreneurship spirit dan kemampuan pribadi (mental) menjadi sangat dominan dalam mencapai kesuksesan bagi social entrepreneur.
\end{abstract}

Kata kunci: Kewirausahaan Sosial, Daur Ulang, Inovasi Produk, Bank Sampah

\begin{abstract}
Social entrepreneurship has become an essential for every social entrepreneur to create, lead, and pursue an innovative solution to social problems through relationship with others and doing activity that creates social values in society. Social entrepreneurship typically furthers broad social, cultural, and environmental goals and is commonly associated with the voluntary and not-for-profit sectors. Trash has become a problems in society. As capital city of Indonesia, Jakarta seriously fight the waste problems which creates an environmental issues. But for some people, trash has become a solution for raising money if it's reuse, recycle, and reproduce into valuable and innovative products. Entrepreneurship typically measure performance in profit and return, but social entrepreneurs also take into account a positive return to society which brings social mission, innovation, and change in society. The present of Waste Bank TAL in society is regarded as important as its and contributed positively to environment, but still left some problems in their management such as lack of marketing plan, operational procedures, and quality control. Given training of social entrepreneurship at Waste Bank TAL has become an important to get those potential features of entrepreneurship and develop
\end{abstract}


them altogether. The methods of training is given through mini workshop, socialization, and evaluation on the unit of business. The results shows the entrepreneurship spirit and self motivation (entrepreneurial mindset) has become a dominant in successful social entrepreneur.

\section{Keywords: Social Entrepreneurship, Recycle, Product Innovation, Waste Bank}

\section{PENDAHULUAN}

Kewirausahaan sosial adalah proses dalam menemukan solusi dan inovasi dalam permasalahan sosial dan pelaku kewirausahaan sosial disebut sebagai wirausaha sosial (social entrepreneur). Kewirausahaan sosial memiliki misi untuk menciptakan dan menjaga nilai-nilai sosial kemasyarakatan melalui adaptasi dan pembelajaran, berpikir bisnis baik untuk menghasilkan keuntungan maupun tidak (notfor profit) (Peter, 2000).

Wiyono (2019) berpendapat bahwa sebagai sebuah ide, kewirausahaan sosial berasal dari definisi wirausaha sebagai kegiatan ekonomi, yang berlandaskan pada falsafah dasar manusia sebagai mahluk ekonomi. Ide ini sudah diungkapkan jauh sebelum adanya definisi kewirausahaan sosial. Kewirausahaan sosial adalah kewirausahaan yang ditujukan untuk kepentingan masyarakat bukan sekadar memaksimalkan keuntungan pribadi. Kewirausahaan sosial biasa disebut 'pengembangan masyarakat' atau "organisasi bertujuan sosial' (Tan et all, 2005).

Melihat masalah sebagai peluang melupakan ciri khas dari kewirausahaan sosial, dimana bisnis model baru ditemukan berdasarkan asas manfaat bagi pemberdayaan masyarakat sekitar. Hasil yang ingin dicapai bukan keuntungan materi atau kepuasan pelanggan, melainkan bagaimana gagasan yang diajukan dapat memberikan dampak baik bagi masyarakat. Mereka seperti seseorang yang sedang menabung dalam jangka panjang karena usaha mereka memerlukan waktu dan proses yang lama untuk dapat terlihat hasilnya. Wirausaha sosial menjadi fenomena sangat menarik saat ini karena perbedaan-perbedaannya dengan wirausaha tradisional yang hanya fokus terhadap keuntungan materi dan kepuasan pelanggan serta signifikansinya terhadap kehidupan masyarakat.

Berdasarkan pengertian diatas, dapat kita tarik kesimpulan bahwa kewirausahaan sosial (social entrepreneurship) merupakan sebuah istilah turunan dari kewirausahaan. Gabungan dari kedua kata, yaitu social yang artinya kemasyarakatan dan entrepreneurship yang artinya kewirausahaan. Kewirausahaan memiliki misi untuk mensejahterakan masyarakat sekitar lingkungan wirausaha sosial hidup dan bermasyarakat.

Sampah telah menjadi masalah tidak hanya di Indonesia namun juga di dunia. Permasalahan sampah muncul karena kurangnya perhatian terhadap sampah lalu menyebabkan kerusakan dan menyisakan kotoran dimana-mana. Masalah sampah adalah masalah klasik yang merusak kehidupan manusia karena akibat yang ditimbulkannya lebih parah dari kotoran sampah itu sendiri. Pada tahun 2016, jakarta memproduksi sampah hingga 6000-7000 ton dan menyumbang sekitar $13 \%$ sampah plastik yang menggenangi lautan (Kalimasyada, 2017).

Sebagai ibukota Indonesia, Jakarta memiliki banyak permasalahan yang sampai saat ini masih belum terselesaikan. Satu diantaranya adalah masalah lingkungan, terutama upaya mengurangi banyaknya sampah yang berserakan tidak pada tempatnya. Sampah masih menjadi permasalahan di beberapa kawasan di Jakarta, peluang ini menarik minat sebagian kecil masyarakat untuk dijadikan peluang dan mendulang uang. Namun tetap saja jumlahnya yang banyak sering kali menyebabkan masalah baru di ibukota.

Perilaku membuang sampah sembarangan juga menjadi penyebab dari banyak nya sampah yang tidak terkelola dengan baik. Keterbatasan kemampuan pemerintah dalam mengelola sampah, hendaknya disampaikan kepada masyarakat untuk membentuk opini kesadaran akan kebersihan lingkungan dengan cara menggandeng organisasi masyarakat, kampuskampus, dan lembaga swadaya masyarakat seperti bank sampah.

Program daur ulang sampah yang dikenalkan oleh pemerintah dikenal dengan nama $3 \mathrm{R}$ (reduce, reuse, dan recycle) sampah bisa menjadi solusi dalam melindungi lingkungan dari kehancuran yang disebabkan oleh sampah (Farida, 2012). Selain dari program pengurangan sampah, program daur ulang 
sampah juga sangat efektif dalam memanfaatkan sampah yang masih bisa di pakai, apalagi jika di olah menjadi produk inovatif yang bisa menghasilan keuntungan bagi pelakunya (Kuratko, 2009), serta masyarakat di sekitarnya. Salah satu solusi dari permasalahan sampah di Jakarta adalah didirikannya bank sampah. Bank sampah akhir-akhir ini cukup populer di Indonesia, keberadaannya dianggap positif dan membantuk dalam mengurangi jumlah sampah (Fabianus, 2014), karena program daur ulang sampah menjadi produk yang inovatif dan bercorak khas tersendiri. Masyarakat kecil disekitar ulujami pesanggrahan Jakarta Timur selama lima tahun terakhir telah berhasil mengubah sampah menjadi berkah melalui Bank Sampah TAL yang didirikan pada bulan Agustus 2014 oleh Ibu Tri Sugiarti.

Bank Sampah TAL merupakan sebuah usaha sosial kecil yang memproses sampah plastik dan kertas dan mengubahnya menjadi barang dan peralatan berharga bagi kehidupan sehari-hari. Melalui brand produk "Kreasi Menik", Bank Sampah TAL sudah mulai menjual produknya tidak hanya di pasar domestik namun juga ke mancanegara. Kesuksesan tersebut tentunya karena di dukung oleh Badan Ekonomi Kreatif dan kementerian Pariwisata Indonesia. Namun belum maksimal.

Dari observasi yang sudah dilakukan, maka potret dari permasalahan yang ada pada usaha Bank Sampah TAL di wilayah kecamatan Pesanggrahan Jakarta Selatan adalah Pertama, kurangnya pemahaman mengenai ilmu kewirausahaan dasar, dan perbedaannya dengan kewirausahaan sosial. Maka perlu disosialisasikan dan diajarkan perbedaan dasar antar keduanya khususnya kepada pemilik dan pengelola bank sampah. Kedua, kurangnya praktek ilmu kewirausahaan dasar seperti merek, pemasaran, penjualan, hingga membangun jaringan kewirausahaan. Ketiga, kurangnya kesadaran dan keyakinan masyarakat akan produk daur ulang yang menghasilkan uang. Maka, disini perlu ditanamkan inovasi produk yang memiliki daya saing khususnya bagi industri kreatif tanah air sehingga menarik minat masyarakat untuk terlibat langsung dalam memproduksi produk daur ulang, lalu memanfaatkannya untuk keperluan sehari-hari.

Dalam upaya meningkatkan taraf hidup dan mengembangkan kewirausahaan sosial, maka perlu adanya kehadiran kegiatan semacam bank sampah mandiri, untuk menyerap sampah yang tidak terpakai dan diubah menjadi uang. Maka dari pada itu, sebagai bentuk kontribusi positif dan pengabdian kepada masyarakat, maka dosen di prodi administrasi bisnis melakukan kegiatan pengabdian kepada masyarakat di Bank Sampah TAL. Kegiatan ini melibatkan dosen, pengelola bank sampah, dan masyarakat sekitar yang bertujuan untuk meningkatkan dan mengembangkan kewirausahaan bank sampah ini.

\section{METODE PELAKSANAAN}

Melihat potensi kewirausahaan sosial yang dijalankan oleh Bank Sampah TAL serta untuk menjawab permasalahan yang telah dijelaskan sebelumnya, maka solusi yang ditawarkan adalah dengan memberikan sosialisasi akan pentingnya ilmu kewirausahaan sosial sebagai ilmu dasar yang harus dimiliki oleh pelaku wirausaha sosial seperti Bank Sampah TAL. Kegiatan sosialisasi dilanjutkan dengan memberikan pelatihan dalam bentuk mini workshop mengenai ilmu kewirausahaan dasar, seperti pembentukan mental wirausaha, pembuatan merek, logo, kartu nama, brosur, pemasaran, strategi penjualan dan reseller. Selain itu, juga ada pelatihan pengenalan ilmu kewirausahaan sosial tentang teori ilmu kewirausahaan sosial (social entrepreneurship) lalu dilanjutkan dengan teori ilmu kewirausahaan (entrepreneurship). Materi yang diberikan adalah materi dari kurikulum dasar kewirausahaan pada Tanri Abeng University di khususkan bagi mahasiswa semester pertama dan bisa juga diterapkan untuk umum. Materi kewirausahaan sosial terdiri dari tiga dimensi sosial yaitu, misi sosial (social mission), inovasi sosial (social innovation), dan perubahan sosial (social change). Sedangkan materi ilmu kewirausahaan fokus pada pengembangan merek diantaranya pembuatan logo, kartu nama dan brosur, serta strategi pemasaran, dan penjualan.

Kegiatan pelatihan dilaksanakan pada Hari Senin tanggal 29 Oktober 2018, bertempat di kantor Bank Sampah TAL, dengan target peserta dari pengelola Bank Sampah TAL, dan beberapa mahasiswa tingkat akhir program studi ilmu administrasi bisnis Tanri Abeng University (TAU), dan masyarakat umum. Melalui sosialisasi dan pelatihan tersebut, diharapkan pengurus dan pengelola bank sampah terutama mendapatkan pengetahuan dan menerapkan 
pelajaran yang didapat dalam menyelesaikan permasalahan sampah kertas dan plastik di ibukota khususnya di wilayah ulujami pesanggrahan. Kegiatan ini tidak hanya di ikuti oleh pengelola bank sampah, dan beberapa mahasiswa TAU, namun juga melibatkan masyarakat sekitar bank sampah sehingga pesan penting tentang kesadaran kewirausahaan sosial dalam pengelolahan sampah dapat sampai kepada masyarakat luas. Bagi bank sampah, ilmu yang didapat dapat segera di praktekkan dalam berwirausaha sosial.

\section{HASIL DAN PEMBAHASAN}

Pada saat kegiatan ini terlaksana, terdapat peserta berjumlah 20 orang yang terdiri dari 5 orang pengurus bank sampah, 10 orang mahasiswa, dan 5 orang masyarakat umum. Kegiatan pelatihan pengembangan kewirausahaan sosial ini merupakan bagian dari kegiatan pengabdian kepada masyarakat yang dilakukan oleh dosen prodi administrasi bisnis Tanri Abeng University. Kegiatan pelatihan yang berlokasi di kantor bank sampah ini juga

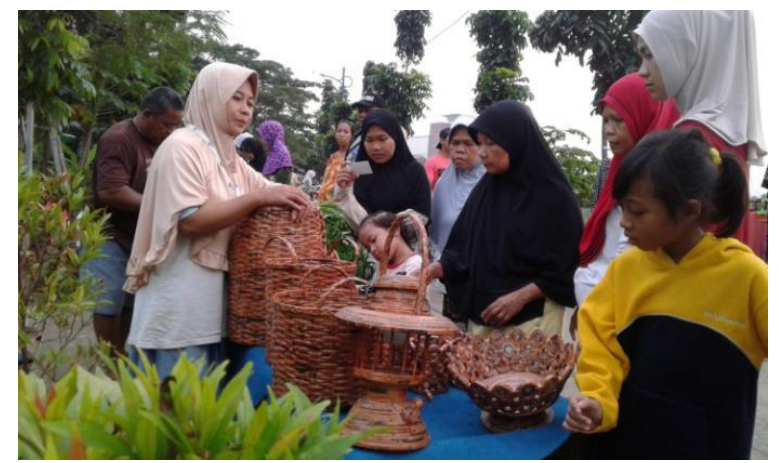

Kegiatan Promosi Produk di Sekitar Lingkungan meliputi kegiatan pembuatan produk inovatif dengan bahan dasar kertas dan plastik bekas dan pengembangan kewirausahaan sosial.

Pembicara pada kegiatan ini disampaikan oleh bapak Didip Diandra, MBA yaitu mengenai kewirausahaan sosial dan ilmu kewirausahaan dasar. Kemudian dilanjutkan dengan mini workshop mengenai pengembangan daur ulang produk sampah dari kertas dan plastik khususnya bidang kewirausahaan dan belajar sedikit teori manajemen dasar pemasaran untuk memperdalam ilmu kewirausahaan sebelumnya. Permasalahan utama dari pengembangan kewirausahaan bank sampah ini adalah rendahnya nilai merek produk yang di usung oleh bank sampah dengan nama "kreasi menik". Maka, peserta pelatihan diajarkan bagaimana menciptakan logo yang benar bagi usaha, menciptakan merek yang menjual beserta tagline atau semboyannya, membuat kartu nama, dan brosur. Logo usaha bisa diambil dari gambar produk yang sudah dihasilkan oleh bank sampah. Produk yang variatif dan menjual diantaranya seperti pada Gambar 2:

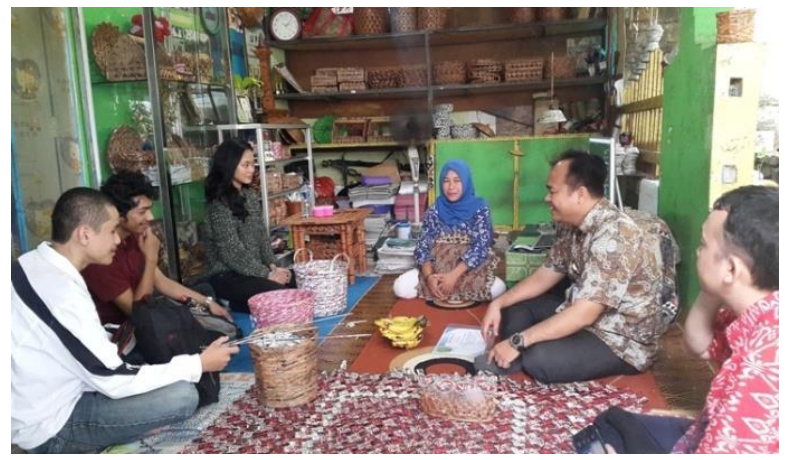

Diskusi dan Wawancara Perkembangan Usaha

Gambar 1. Kegiatan Bank Sampah TAL dan Saat Sesi Wawancara

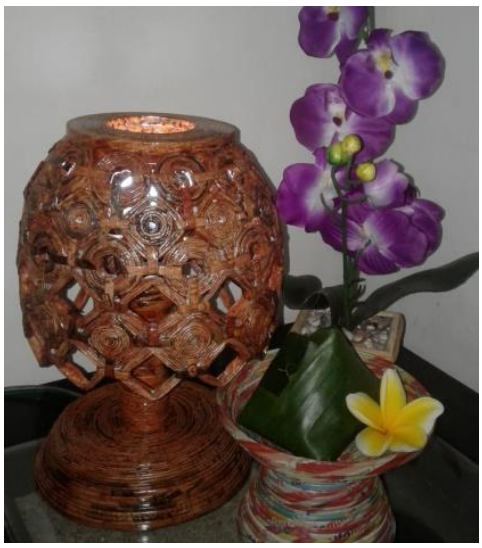

Lampu Hias Ruangan

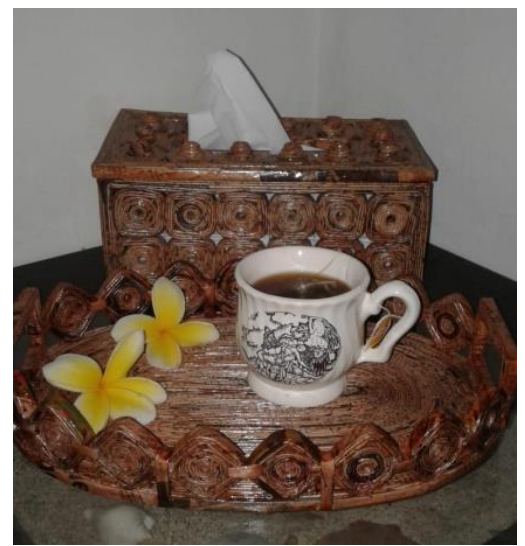

Kotak Tisu dan Tampan Air Minum

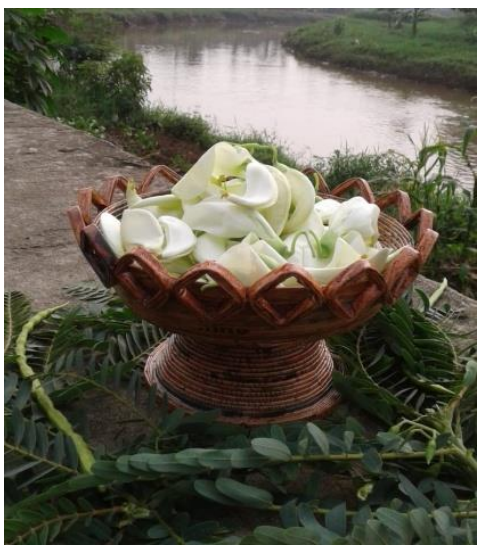

Tempat Buah-buahan 


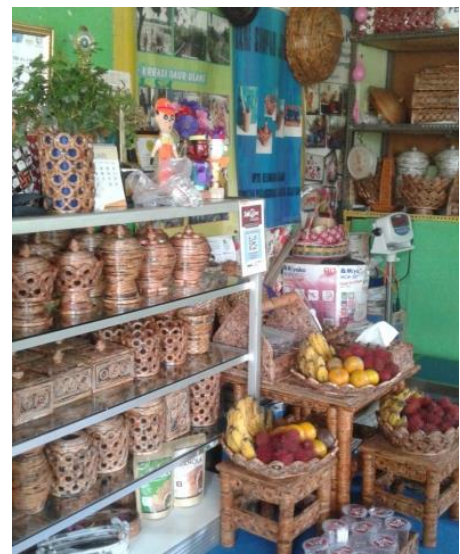

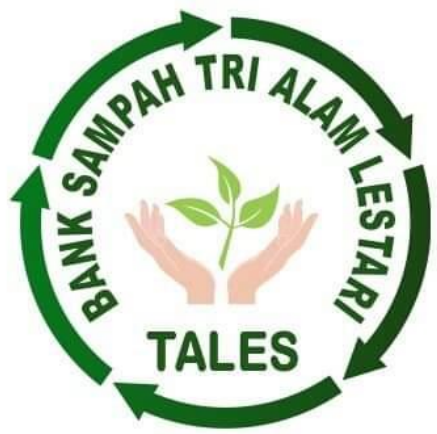

Logo Bank Sampah TAL

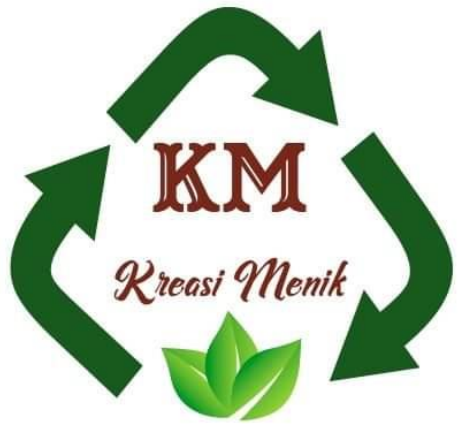

Brand Produk Yang Dihasilkan bernama "Kreasi Menik"

Gambar 2. Inovasi produk yang dihasilkan oleh Bank Sampah TAL Beserta Logo dan Brand Merek

Pelaksana mengakui bahwa kegiatan pelatihan ini kurang berjalan dengan lancar disebabkan rendahnya pendidikan pengelola bank sampah ini, bagi mereka teori tidak terlalu penting yang penting produksi barang sebanyak mungkin, dijual dan menghasilkan uang. Namun secara teori ilmu kewirausahaan, usaha apapun harus dimulai dengan ide dan strategi pengembangan kewirausahaan, dengan begitu maka usaha dapat berkembang dan diterima di tengah masyarakat. Kesulitan utama dalam mengajarkan ilmu kewirausahaan adalah harus menggunakan bahasa yang sangat mendasar sekali, tidak boleh ada bahasa inggris sedikitpun kecuali bagi mahasiswa, sementara pengelola bank sampah dan masyarakat masih sangat sulit untuk memahami istilah-istilah ilmu kewirausahaan yang kebanyakan menggunakan bahasa inggris atau latin. Selain itu, minimnya pengetahuan tentang kewirausahaan juga menjadi hambatan dalam pengembangan usaha. Kesulitan-kesulitan tersebut harus dievaluasi dan dicarikan solusi sebelum kegiatan pelatihan kewirausahaan sosial di mulai di masa mendatang.

Sebagai bahan evaluasi dalam kegiatan ini, para peserta diminta untuk mengisi formulir penilaian unit usaha yang sudah disiapkan oleh pemateri. Dari 20 peserta, ada 10 peserta yang mengumpulkan nilai atau hanya $50 \%$ saja yang bersedia mengisi formulir dan memberikan evaluasi pada kegiatan pelatihan ini, hal ini terjadi karena sedikitnya pengetahuan peserta lain untuk memahami pertanyaan dalam formulir. Materi yang disampaikan dalam pelatihan ini merupakan materi yang berkaitan tentang pentingnya belajar ilmu kewirausahaan dasar dalam mengembangkan usaha bank sampah.

Terdapat 10 pertanyaan dalam evaluasi kewirausahaan sosial bank sampah dengan nilai skor rata-rata dari 10 peserta yang mengisi formulir yang dijelaskan sebagai berikut:

Tabel 1. Formulir Penilaian Unit Usaha

\begin{tabular}{cccc}
\hline NO & URAIAN & PERTANYAAN & NILAI/SKOR \\
\hline $\mathbf{1}$ & $\begin{array}{c}\text { Entrepreneurship } \\
\text { Spirit }\end{array}$ & $\begin{array}{c}\text { Passion, Leadership } \text { dan Ambisi menjadi } \\
\text { Social Entrepreneur }\end{array}$ & A \\
& Ide \& Inovasi & Ide yang orisinil dan inovatif, ide yang \\
Sosial & sudah ada & A \\
\hline
\end{tabular}




\begin{tabular}{|c|c|c|c|}
\hline NO & URAIAN & PERTANYAAN & NILAI/SKOR \\
\hline 3 & $\begin{array}{l}\text { Detail Gambaran } \\
\text { Produk/ Jasa }\end{array}$ & $\begin{array}{l}\text { Produk artinya adalah kepuasan konsumen, } \\
\text { maka yang perlu diperhatikan adalah fitur } \\
\text { utamanya, keunikan produk Anda, } \\
\text { kelebihan dan keunggulan produk, peluang } \\
\text { pasar, kebutuhan pelanggan, kemampuan } \\
\text { menciptakan produk, serta potensi loyalitas } \\
\text { konsumen }\end{array}$ & A \\
\hline 4 & Analisa Pasar & $\begin{array}{c}\text { Yaitu membuat Market Brief, } \\
\text { menggambarkan kondisi pasar secara jelas } \\
\text { dan detail, segmen dan target pasar, } \\
\text { kesulitan memasuki pasar, dll. }\end{array}$ & $\mathrm{B}$ \\
\hline 5 & $\begin{array}{l}\text { Perencanaan } \\
\text { Pemasaran }\end{array}$ & $\begin{array}{l}\text { Menggunakan } 7 \text { Bauran Pemasaran } \\
\text { (Product, Price, Place, Promotion, People, } \\
\text { Process, and Physical Evidence). Selain itu } \\
\text { juga pilih sistem pembayaran yang } \\
\text { fleksible, metode promosi, dan jaringan } \\
\text { distribusi }\end{array}$ & B \\
\hline 6 & $\begin{array}{l}\text { Rencana } \\
\text { Operasional }\end{array}$ & $\begin{array}{l}\text { Lihat fasilitas yang digunakan serta } \\
\text { prosedur operasional, lakukan berdasarkan } \\
\text { standar dan quality control yang sudah } \\
\text { ditetapkan }\end{array}$ & B \\
\hline 7 & $\begin{array}{l}\text { Manajemen dan } \\
\text { Organisasi }\end{array}$ & $\begin{array}{c}\text { Peraturan organisasi, struktur organisasi, } \\
\text { penanggung jawab dan latar belakang } \\
\text { sumber daya manusia yang ada di balik } \\
\text { organisasi }\end{array}$ & $\mathrm{B}$ \\
\hline 8 & Rencana Keuangan & $\begin{array}{c}\text { Modal awal, sumber pendanaan, analisa } \\
\text { keuangan, balance sheet, income statement, } \\
\text { studi kelayakan keuangan, lakukan } \\
\text { perhitungan yang matang }\end{array}$ & B \\
\hline 9 & $\begin{array}{l}\text { Ringkasan } \\
\text { (Summary) }\end{array}$ & $\begin{array}{l}\text { Dapat memberikan gambaran mengenai } \\
\text { proposal bisnis yang dibuat secara singkat, } \\
\text { konsisten, dan sistematik }\end{array}$ & $\mathrm{B}$ \\
\hline 10 & $\begin{array}{l}\text { Kemampuan } \\
\text { Pribadi }\end{array}$ & $\begin{array}{l}\text { Menguasai semua isi usaha, serta mampu } \\
\text { meyakinkan rekan, sahabat, investor, bank } \\
\text { bahwa usaha Anda memiliki potensi bisnis }\end{array}$ & A \\
\hline
\end{tabular}

Dimana metode penilaiannya dihitung dengan cara manual menggunakan microsoft $\mathrm{xl}$ dengan rata-rata nilai (range score) sebagai berikut:
Tabel 2. Range Score Penilaian

\begin{tabular}{ccc}
\hline NILAI & MIN & MAKS \\
\hline A & 80 & 100 \\
B & 60 & 80 \\
C & 40 & 60 \\
D & 20 & 40 \\
E & \multicolumn{2}{c}{$<20$} \\
F & \multicolumn{2}{c}{ Kosong/Empty }
\end{tabular}


Rata-rata nilai yang masuk berdasarkan data diatas tergambar dengan hasil persentase sebagai berikut:

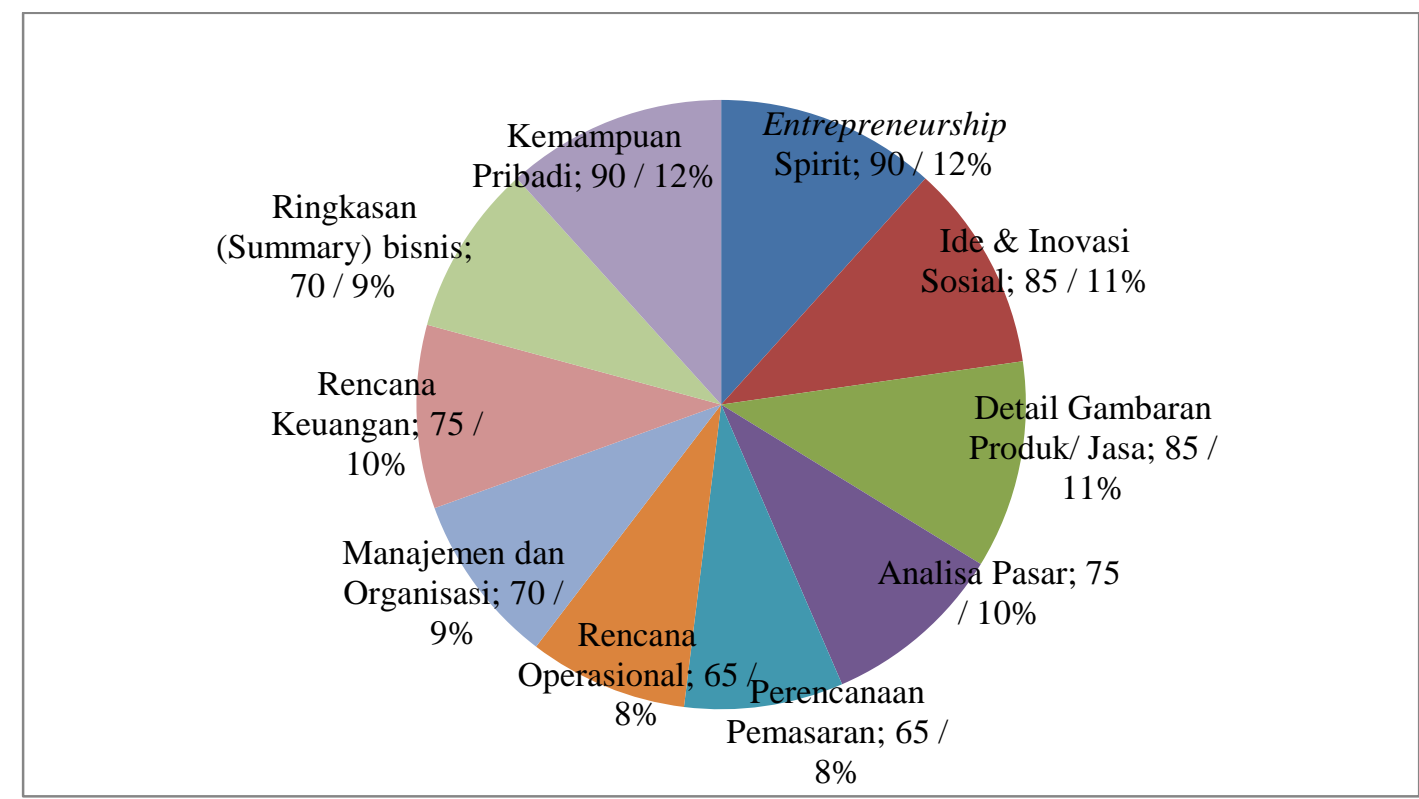

Gambar 3. Persentase Hasil Penilaian Unit Usaha

Grafik di atas menjelaskan tentang hasil penilaian unit usaha Bank Sampah TAL. Untuk mencapai misi dalam kegiatan ini, maka diperlukan semacam tes dan alat pengukur yang mengetahui kekurangan dan kelebihan dari target kegiatan. Dari penilaian yang ada, hanya pelaku usaha sosial dan kemampuan pribadi masing-masing mendapatkan nilai skor rata-rata 90 atau $12 \%$ dari total penilaian. Hal tersebut menjadikan pelaku usaha sosial mampu membawa misi sosial dengan menciptakan inovasi sosial melalui pemanfaatan limbah sampah kertas dan plastik. Sementara ide orisinil dan inovatif dalam bentuk keunikan produk yang berorientasi pada kebutuhan pasar mendapatkan nilai skor rata-rata 85 atau $11 \%$ dari total penilaian. Dengan adanya ide-ide bisnis yang unik serta kemampuan menciptakan produk yang inovatif dan berdaya saing, maka Bank Sampah TAL sebenarnya sudah mendapatkan tempat di hati konsumennya, yang kemudian loyal terhadap produk yang dihasilkan usaha ini. Solusi kemudian muncul setelah segmen dan target pasarnya terbentuk melalui promosi produk dan pendekatan birokrasi yang sudah sudah dilakukan seperti melaporkan rencana kegiatan dan output yang dihasilkan secara rutin kepada kantor kelurahan setempat.

Selain dari pada itu, usaha ini juga masih punya kelemahan dalam sumber pendanaan terlihat dari grafik diatas yang hanya mendapatkan skor 75 atau $10 \%$ dari total penilaian, ditambah lagi dengan keterbatasan kualitas SDM dan manajemen organisasi yang kurang baik dengan skor 70 atau hanya $9 \%$ saja menjadikan Bank Sampah TAL harus terus berbenah dan melakukan pelatihan yang dibutuhkan.

\section{SIMPULAN DAN SARAN}

Kegiatan pengabdian kepada masyarakat berupa pelatihan pengembangan kewirausahaan sosial kepada Bank Sampah TAL telah selesai dilaksanakan. Target peserta mencapai $100 \%$ dari total 20 peserta yang terdaftar. Kegiatan pelatihan berjalan dengan lancar dan dihadiri oleh pengelola Bank Sampah TAL, mahasiswa akhir administrasi bisnis, dan beberapa masyarakat sekitar kantor bank sampah.

Berdasarkan Gambar 3 diketahui bahwa ambisi Bank Sampah TAL untuk menjadi pelaku usaha sosial (social entrepreneur) dinilai sangat bagus dengan skor rata-rata 90 atau dengan persentase $12 \%$ dari total penilaian, selanjutnya diikuti oleh kemampuan pribadi dalam menguasai semua isi usaha, serta mampu meyakinkan rekan, sahabat, investor, bank bahwa usaha bank sampah ini memiliki potensi bisnis. Sementara perencanaan pemasaran yang meliputi 7 bauran pemasaran seperti produk, harga, tempat, promosi, orang, proses, dan bukti 
fisik serta rencana operasional yang meliputi fasilitas yang digunakan, prosedur operasional, standar dan kualitas kontrol (quality control) yang sudah ditetapkan masih dianggap lemah dengan masing-masing rata-rata skor hanya 65 atau setara dengan $8 \%$ dari total penilaian. Kedua kategori tersebut sudah dijadikan target dalam pelatihan pengembangan kewirausahaan sosial pada Bank Sampah TAL.

Beberapa saran yang dapat diberikan untuk kegiatan berikutnya adalah lebih banyak mengundang masyarakat dari daerah lain untuk mensosialisasikan pentingnya kewirausahaan sosial dengan memanfaatkan limbah kertas dan plastik, lalu mengubahnya menjadi peluang yang menghasilkan uang. Disamping itu, perlunya kesadaran baik dari tingkat pemerintahan pusat hingga perangkat desa untuk membantu pemasaran produk inovatif daur ulang melalui kegiatan bazar hingga pameran berskala nasional maupun international.

\section{DAFTAR PUSTAKA}

Fabianus, Uran. Garbage Bank the Solution to Environmental Problem. 24 Maret 2014 https://www.wvi.org/indonesia/article/garba ge-bank-solution-environmental-problem.
Farida, Annisa N. (2012). 3R (Reduce, Reuse, Recycle) Diakses dari https://www. kompasiana.com/annisa.tekkimits/5528c8b6 f17e6143088b45a4/3r-reduce-reuserecycle> pada 29 Mei 2019.

Kalimasyada, D. (2017). Marketing Strategy Recommendation for Kreasi Menik to Accelerate the Business Growth, Business Administration, TAU, Jakarta.

Kuratko, D.F., (2009). Entrepreneurship, Theory, Process, Practice. 8 Edition. SouthWestern Cengage Learning. Mason, $\mathrm{OH}$. South-Western.

Peter C. Brinckerhoff. (2000). Social Entrepreneurship. Wiley Nonprofit Series. Chapter 1

Tan et al (2005). 'Defining the 'Sosial' in 'Sosial Entrepreneurship': Altruism and Entrepreneurship'. International Entrepreneurship and Management Journal 1, pp 353-365.

Wikipedia.(2019). Kewirausahaan Sosial. Diakses dari https://id.wikipedia.org/wiki/ Kewirausahaan_sosial pada tanggal $30 \mathrm{Mei}$ 2019.

Wiyono A. (2019). Kewirausahaan Sosial, Perkembangan, Definisi dan Kesimpulan. Diakses dari https://genagraris.id/see/ kewirausahaan-sosial-perkembangandefinisi-dan-kesimpulan pada 30 Mei 2019. 